\title{
Aouati M. \\ IMPROVING THE ACCURACY OF CLASSIFYING RULES FOR CONTROLLING THE PROCESSES OF DECULFURATION AND DEPHOSPHORIZATION OF Fe-C MELT
}

\begin{abstract}
Об'єктом дослідження є процес функціонування хіміко-технологічної системи з двох послідовно включених агрегатів, призначеної для отримання Fе-C розплаву. Цей процес ощінюється на основі класифікаційних правил, що дозволяє виявити ту складову системи, за якою виявлено відхилення режиму роботи від нормального за хімічним аналізом вмісту сірки та фосфору. Такий розгляд дозволяє визначити повноту процесів десульфуращї та дефосфорачї Fе-C розплаву. Одним з найбільш проблемних місць є відсутність систематизованих даних щодо процедур визначення можливих відхилень від нормального режиму функціонування агрегатів за повнотою процесів десульфурації та дефосфоращіі.

В ході дослідження використовувалися методи параметричної класифікаиї, які дозволяють отримувати аналітичний опис дискримінантної функцї та на основі порівняння ї̈ значень в заданій точці простору факторів-ознак з пороговим значенням відносити об'єкт до одного з класів. В даному дослідженні кожен з класів характеризує агрегат хіміко-технологічної системи за вмістом сірки та фосфору в Fе-C розплаві.

Отримані результати дозволяють стверджувати щодо можливості побудови ломаної кривої, поділяючої класи, з використанням методів параметричної класифікації. Це пов'язано з тим, шо запропонована n’ятикрокова процедура вибору області вхідних даних забезпечує можливість зняти одне з обмежень на використання методів параметричної класифікащї, а саме - вимогу щодо рівності коваріачійних матрищь. Запропонована прочедура має ряд особливостей, зокрема вибір області вхідних даних для розрахунку коефічієнтів дискримінантної функцї та порогових значень визначається через вершини планів повного факторного експерименту. Завдяки цьому забезпечується можливість отримання стовідсоткової точності класифікації в областях, що відповідають своєму планові. У порівнянні з результатами побудови класифікуючих правил за загальною вибіркою даних, тобто за усіма точками простору факторів-ознак, а не лише за точками обраного плану, це не надає значних переваг. Але з точки зору отримання форми поділяючої кривої, відмінної від лінійної, це може надати переваги, якщо вибірки вхідних даних погано розділюються.

Ключові слова: хіміко-технологічна система, $\mathrm{Fe}$-C розплав, класифікуючі правила, статистична класифікація, дискримінантна функція.
\end{abstract}

\section{Introduction}

Diagnostics of chemical-technological processes in industrial conditions is one of the most important tasks. This is especially important in automated chemical-technological systems that are complex in their organization. The complexity of the structure and organization of such systems affects the reliability indicators. And if the units of such systems are connected with each other sequentially, it is important to ensure the quality of the intermediate product - leaving the previous unit and coming to the next one. In conditions when chemical reactions occurring in such aggregates have complex mechanisms, it is important to manage these processes, even without having an exact mathematical description. In such cases, it is important to have decision support systems that include elements of diagnostics of chemical-technological processes. These elements must include some classifying rules that allow the current state of the process to be assigned to different classes. For example, these may be the classes «normal mode» or «deviations from the normal mode». By the nature of the product coming from the output of one unit to the input of another, such classes can be «quality product» or «poor quality product». Therefore, the issues of building classifying rules that provide a high degree of quality recognition of the situation or the state of the product are relevant.

\section{The object of research and its technological audit}

The object of research is the process of functioning of the chemical-technological system of two series-connected units, designed to produce $\mathrm{Fe}-\mathrm{C}$ melt. This system was considered in [1] and its principle of operation is as follows. The first unit produces at the outlet a liquid Fe-C melt, which is formed on the basis of the thermal countercurrent flowing in this unit, which is structurally a shaft type furnace. Heat is transferred in the presence of carbon as a result of fuel combustion processes, and there are various zones along the height of a shaft furnace in which oxidation and reduction reactions take place (1)-(4).

$$
\begin{aligned}
& \mathrm{C}+\mathrm{O}_{2} \rightarrow \mathrm{CO}_{2}, \Delta G^{0}=-396450+0.08 T, \mathrm{~J}, \\
& 2 \mathrm{C}+\mathrm{O}_{2} \rightarrow 2 \mathrm{CO}, \Delta G^{0}=-229030-172.13 T, \mathrm{~J}, \\
& 2 \mathrm{CO}+\mathrm{O}_{2} \rightarrow 2 \mathrm{CO}_{2}+\Delta H, \Delta G^{0}=-565390+175.17 T, \mathrm{~J},
\end{aligned}
$$




$$
\mathrm{CO}_{2}+\mathrm{C} \rightarrow 2 \mathrm{CO}, \Delta G^{0}=172130-177.46 T, \mathrm{~J} .
$$

The quality of the product ( $\mathrm{Fe}-\mathrm{C}$ melt) is determined by the content of sulfur (S) and phosphorus (P) in it. The greater the residual content in the melt of these elements, the lower the product quality.

The process of functioning of the first unit involves the operations of sulfur removal (desulfurization) and phosphorus removal (dephosphorization). To do this, calcium carbonate $\left(\mathrm{CaCO}_{3}\right)$ is loaded into the furnace, which at a certain height of the shaft furnace begins to decompose by the reaction (5). This is due to the fact that at a certain height of the furnace due to counterflow, when the burning gases release their heat to the countercurrent flow of $\mathrm{CaCO}_{3}$, the process of dissociation begins. The composition of gases having a temperature of $1700-1800{ }^{\circ} \mathrm{C}$ in the combustion zone consists mainly of a mixture of $\mathrm{CO}$ and $\mathrm{CO}_{2}$.

$$
\mathrm{CaCO}_{3} \rightarrow \mathrm{CaO}+\mathrm{CO}_{2}
$$

The equilibrium constant of the reaction of dissociation of carbonate (5) has the form:

$$
\lg K_{p}=-\Delta H^{0} / 19.144 \cdot 1 / T+\Delta \mathrm{S}^{0} / 19.144
$$

$\mathrm{CaO}$ resulting from reaction (5) reacts with iron sulfide (FeS) according to reaction (7), helping to remove $\mathrm{CaS}$ in the slag.

$$
\mathrm{FeS}+\mathrm{CaO} \rightarrow \mathrm{CaS}+\mathrm{FeO} .
$$

In parallel, in the melt, the reaction of the interaction of iron sulfide with manganese proceeds according to reaction (8), as a result of which manganese sulfide passes into the slag from $\mathrm{Fe}-\mathrm{C}$ melt.

$\mathrm{FeS}+\mathrm{Mn} \rightarrow \mathrm{MnS}+\mathrm{Fe}$.

In the melt-slag reaction system, the dephosphorization reaction of the form (9), (10) is developed.

$$
\begin{aligned}
& \mathrm{P}_{2} \mathrm{O}_{5}+4 \mathrm{CaO} \rightarrow \mathrm{Ca}_{4} \mathrm{P}_{2} \mathrm{O}_{9} . \\
& \mathrm{P}_{2} \mathrm{O}_{5}+5 \mathrm{C} \rightarrow 2 \mathrm{P}+5 \mathrm{CO} .
\end{aligned}
$$

The technological diagram with a description of chemical processes for the first unit of the chemical-technological system under consideration is shown in Fig. 1.

The second unit of the chemical-technological system under consideration has a different type of energy carrier and it does not contact the product with the fuel. Heat comes from the electric arcs that form the $\mathrm{Fe}-\mathrm{C}$ melt bath. In this case, chemical reactions develop at the melt-slag interface.

The desulfurization process proceeds according to reaction (8). It must be said that the nature of the chemical reactions that lead to the removal of sulfur melt from Fe-C depends on the lining of the second unit. If it consists predominantly of $\mathrm{SiO}_{2}$, then the possibilities for complete desulfurization are limited. If the furnace has a basic lining, then the decrease in the sulfur content is directly propor- tional to the temperature and holding time of the melt in the furnace. Factors affecting the intensity of these reactions are the increased fluidity of the slag and the content of the following compounds in it: $\mathrm{CaO}, \mathrm{CaC}_{2}$, $\mathrm{CaF}_{2}[2]$.

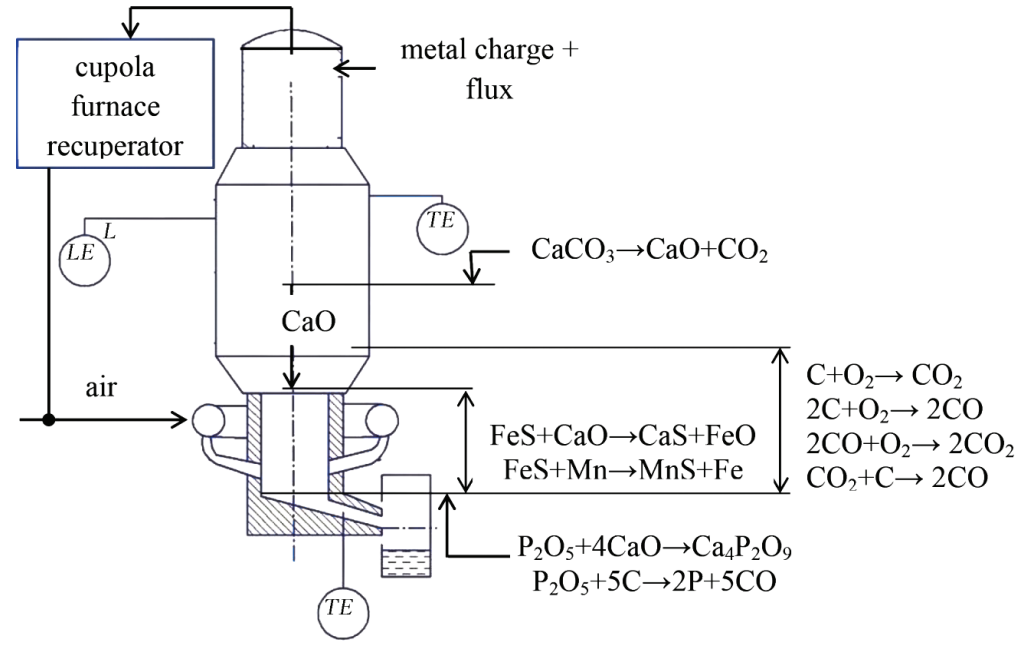

with a description of the chemical
of the chemical-technological system

The desulfurization process proceeds according to reaction (11), and the distribution of the phosphorus content between the slag and the Fe- $\mathrm{C}$ melt is described by equation (12) [3].

$$
\begin{aligned}
& 2[\mathrm{P}]+5(\mathrm{FeO})=\left(\mathrm{P}_{2} \mathrm{O}_{5}\right)+5[\mathrm{Fe}], \\
& \frac{(\mathrm{P}, \%)}{[\mathrm{P}, \%]}=0.776\left[\frac{(\mathrm{CaO}) \cdot(\mathrm{FeO})}{\left(\mathrm{SiO}_{2}\right)}\right]^{0.69} .
\end{aligned}
$$

Chemical analysis shows the complex nature of changes in the phosphorus content in the smelting process. It can be noted that the connection between the decrease in the phosphorus content and the $\mathrm{FeO}$ content and the temperature of the $\mathrm{Fe}-\mathrm{C}$ melt is complex. The most complete dephosphorization degree takes place at a temperature of 1350-1450 ${ }^{\circ} \mathrm{C}$. The excess temperature of the $\mathrm{Fe}-\mathrm{C}$ melt above this limit leads to the onset of the reaction of reduction of $\mathrm{P}$ from the slag at the interface [2].

The technological diagram with the description of chemical processes for the second unit of the chemicaltechnological system under consideration is shown in Fig. 2.

Table 1 shows the results of chemical analysis of sulfur (S) and phosphorus (P) content in $\mathrm{Fe}-\mathrm{C}$ melt at the output from both units of the system [1]. The results are shown in normalized form, the valuation is carried out according to the well-known formula:

$$
x_{i n}=\frac{x_{i}-\bar{x}_{i}}{I_{i}},
$$

where $x_{i n}$ - the normalized value of the $i$-th input variable ( $i=1$ for $\mathrm{S}, i=2$ for $\mathrm{P}$ ); $x_{i}$ - natural values of input variables $(i=1$ for $\mathrm{S}, i=2$ for $\mathrm{P}) ; \bar{x}_{i}-$ mathematical expectations of input variables; $I_{i}$ - intervals of variation of input variables. 


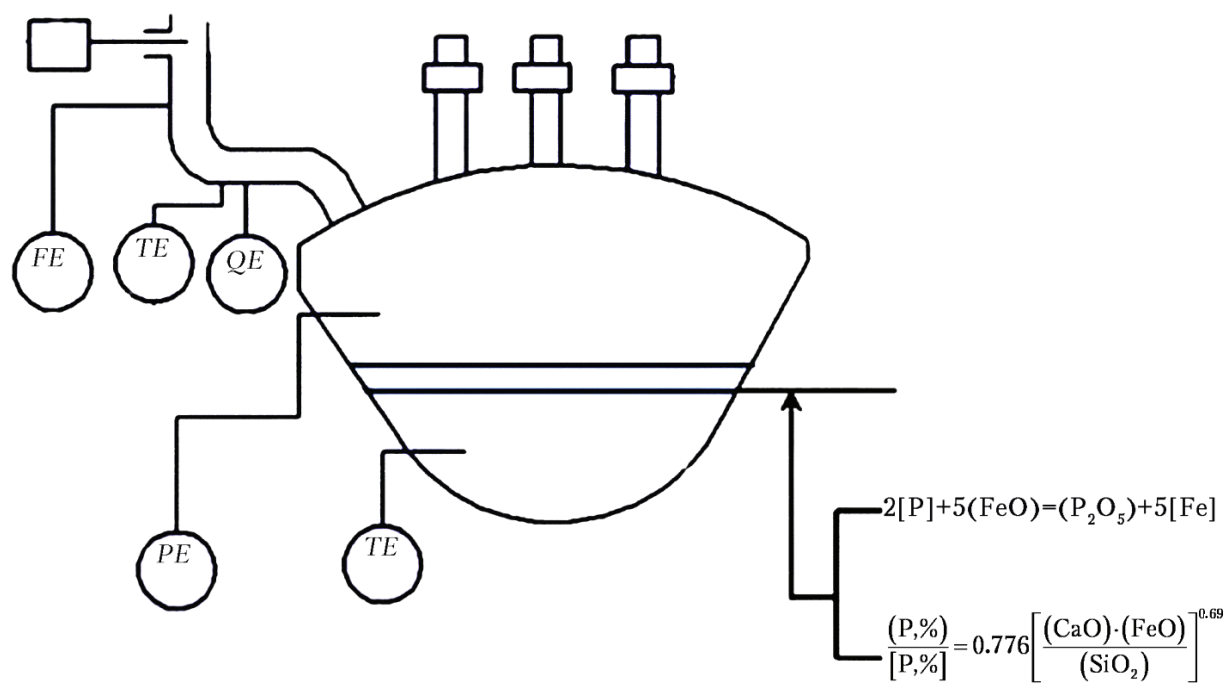

Fig. 2. Technological diagram with a description of chemical processes for the second unit of chemical-technological system

Table 1

The results of chemical analysis of sulfur content (5) and phosphorus (P) in $\mathrm{Fe}-\mathrm{C}$ melt at the output from both units of the system

\begin{tabular}{|c|c|c|c|c|}
\hline \multirow{3}{*}{$\begin{array}{l}\text { Melting } \\
\text { number }\end{array}$} & \multicolumn{2}{|c|}{$\begin{array}{l}\text { Sulfur and phosphorus content } \\
\text { in Fe- }[\text { melt at the outlet of } \\
\text { the first unit (class } A \text { ) }\end{array}$} & \multicolumn{2}{|c|}{$\begin{array}{l}\text { Sulfur and phosphorus content } \\
\text { in Fe- } C \text { melt at the outlet of } \\
\text { the second unit (class } B \text { ) }\end{array}$} \\
\hline & $5, \%$ & $\mathrm{P}, \%$ & $5, \%$ & $\mathrm{P}, \%$ \\
\hline & $x_{1}$ & $x_{2}$ & $x_{1}$ & $x_{2}$ \\
\hline 1 & -0.7 & -0.08 & 1 & -0.63 \\
\hline 2 & -0.7 & 0.08 & 0.17 & -0.26 \\
\hline 3 & -0.2 & -0.28 & 0.12 & -0.81 \\
\hline 4 & -0.68 & -0.23 & 0.51 & -0.58 \\
\hline 5 & -0.01 & -0.44 & 0.07 & 0.12 \\
\hline 6 & -1 & 0.08 & -0.66 & -0.67 \\
\hline 7 & -0.66 & 0.64 & -0.46 & -0.95 \\
\hline 8 & -0.59 & 0.38 & -0.56 & -0.3 \\
\hline 9 & -0.59 & 0.28 & -0.8 & -1 \\
\hline 10 & -0.7 & -0.9 & -0.12 & -0.53 \\
\hline 11 & -0.64 & -0.9 & -0.17 & -0.4 \\
\hline 12 & -0.38 & -0.9 & 0.22 & -0.26 \\
\hline 13 & -0.64 & -1 & 0.12 & -0.21 \\
\hline 14 & 0.2 & -0.33 & -0.41 & -0.26 \\
\hline 15 & 1 & -0.18 & -0.37 & -0.3 \\
\hline 16 & -0.25 & 1 & 0.51 & -0.26 \\
\hline 17 & 0.33 & 0.49 & 0.46 & -0.35 \\
\hline 18 & 0.78 & -0.85 & -1 & -0.44 \\
\hline 19 & -0.46 & -0.85 & -0.61 & -0.3 \\
\hline 20 & -0.25 & -0.64 & -0.71 & -0.12 \\
\hline 21 & -0.42 & -0.59 & -1 & -0.02 \\
\hline 22 & -0.46 & -0.9 & 0.46 & -0.72 \\
\hline 23 & -0.05 & 0.49 & -0.27 & -0.86 \\
\hline 24 & -0.36 & 0.44 & -0.56 & -0.16 \\
\hline 25 & -0.25 & 0.23 & -0.27 & -0.49 \\
\hline 26 & -0.31 & 0.44 & -0.17 & -0.91 \\
\hline 27 & -0.33 & -0.08 & -0.27 & 0.26 \\
\hline 28 & -0.35 & -0.18 & -0.17 & -0.02 \\
\hline 29 & -0.7 & -0.18 & 0.66 & -0.86 \\
\hline 30 & -1 & 0.23 & 0.61 & -0.58 \\
\hline 31 & -0.55 & -0.33 & 0.32 & -0.07 \\
\hline 32 & -0.5 & -0.18 & 0.51 & 1 \\
\hline 33 & -0.27 & -0.59 & 0.76 & -0.02 \\
\hline 34 & -0.36 & -0.08 & 0.9 & -0.26 \\
\hline 35 & -0.31 & -0.08 & -0.12 & 0.12 \\
\hline
\end{tabular}

In [1], on the basis of these data, a classification rule of the form (14) is constructed, which yielded good recognition results. Thus, it is noted that the accuracy of the correct classification is determined by the number of correctly classified objects, and in this case it is: $\mathrm{P}(A)=0.914, \mathrm{P}(B)=0.971$.

$$
\begin{aligned}
& x^{j} \in A \text {, if } 329.0798 x_{1}-99.9363 x_{2} \geq 22.27076, \\
& x^{j} \in B \text {, if } 329.0798 x_{1}-99.9363 x_{2}<22.27076 .
\end{aligned}
$$

However, it is noted that there is a reserve for improving accuracy by choosing the optimal range of values for input variables. Under the optimal meant such a choice in which the dispersion matrices of classes $A$ and $B$ will be equal to each other.

\section{The aim and objectives of research}

The aim of research is in clarification of the classifying rule, allowing to identify the unit of chemical-technological system, the process in which did not allow to ensure the specified completeness of desulfurization and dephosphorization. This would make it possible to make sure that the purposeful choice of the range of values of the input variables is material for the accuracy of the classifying rule.

To achieve the aim, the following objectives are set.

1. To select a planning area for building classifying rules.

2. To assess the impact of localization of the selected planning areas on the coefficients of the discriminant function and the magnitude of the threshold values in the classifying rules.

\section{Research of existing solutions of the problem}

In [4], a recurrent procedure for parametric classification is proposed, involving the following steps:

- splitting the sample of experimental data into two classes;

- determination of the parameters of the discriminant function;

- obtaining the vector of initial values in the description of the parameters of the discriminant function; 
- additional training using the stochastic approximation algorithm by applying to the vector of the obtained initial values of a recurrent expression of a certain type.

Such a recurrent procedure ends as soon as the separating function begins to provide the specified classification accuracy, assessed by the probability of correct recognition.

The authors of [4] conclude that the rate of convergence is high, regardless of the laws of the distribution of signs in the diagnostic sample, and high accuracy. However, the effect on recognition indicators obtained on the type of the distribution law of experimental data is not clarified. It is necessary to recognize that on this issue in [4] there is a remark that such a recurrent procedure has advantages over the method of statistical solutions in the accuracy of recognition of objects described by distribution laws in classes other than normal.

The use of parametric classification methods based on Bayesian statistics has been the subject of a number of papers in which classification problems have been solved for specific industrial applications. Thus, the work [5] is devoted to the study of the possibilities of evaluating the properties of materials by constructing classifying rules. And in [6, 7], the possibility of using discriminant functions to diagnose product quality is investigated. However, the performance of the classifying rules constructed in these works is not demonstrated by the calculations of the accuracy of recognition.

Unlike the results of the aforementioned works, the authors of [8] investigate precisely the efficiency of the pattern recognition system. The authors of this paper apply the principle of estimation, based on the use of pre-prepared database of images for classes and input images. The decision rule is based on the Dice similarity criterion, which is used to classify the input images represented by the two-dimensional video image spectrum [9].

It is noted that the use of a large number of feature vectors in the recognition of input images can lead to deterioration in the quality of recognition.

Modern approaches to the problems of improving the accuracy of classification give priority to the use of neural networks, with the main attention of researchers focused on the quality of neural network training. Thus, in [10], the results of applying one of the classical algorithms for developing a decision support subsystem in the neural network pattern recognition system are described. The method proposed by the authors for supporting the adoption of classification decisions provides for the sequential execution of the stages of self-organization of the Kohonen computational neurons, the graduation of the elements of the output vector of the training set, and their final labeling. The authors demonstrate an increase in the accuracy of expert assessments; however, the conditions for the application of the described method have not been proposed. Comparing the results of research [10] and [11], it can be noted that the existing basic «classical» learning models have a number of drawbacks. This conclusion is also justified in [10], in particular, they note the impossibility of doing without one of the learning models when creating universal pattern recognition systems.

In the works cited above, no study of the issue of constructing efficient recognition systems is found in conditions where the components of the image vectors can't be measured with a sufficient degree of accuracy. This disadvantage is compensated by a number of other works in which the tasks of building efficient recognition systems based on clustering are solved, taking into account the fuzziness of the input data. Thus, in [12], it was shown that the use of methods of self-organizing maps (SOM) and the principal component analysis (PCA) for the prediction problem is a more powerful practical tool for the automated identification of characteristic models. However, it should be noted that these models dealt with objects of a specific nature - seismic spectra.

The paper [13] describes an approach based on a point estimate for conditions of fuzzy pattern recognition. In it, the space is considered to consist of two fuzzy sets («Truthful» and «Deceiver»), and performing a sequential matching procedure eliminates ambiguity. The authors note that the proposed method is highly stable, but does not speak of the limitations of the proposed method.

In [14], an approach to data processing for classification based on the use of computational intelligence methods is proposed. The proposed adaptive algorithm for fuzzy clustering using the objective function and constraints of the selected type allows to form a fuzzy partitioning matrix in which objects are divided into clusters (diagnoses). In this case, the shape of the clusters can vary from hypersphere to hyperellipsoid, depending on the shape of the source data. As a feature of this proposed approach, the authors note insensitivity to the ratio of the number of objects to the number of indicators characterizing these objects, as well as to the law of data distribution. However, it is not clarified in the work whether there are requirements on the area of placing the source data in the feature space.

The task of increasing the accuracy of statistical classification based on experiment planning is solved in [15]. It is shown on the example of a test sample that for the localization of vectors-images in the space of factorattributes, it is possible to use plans for a full factorial experiment. In this case, one of the known limitations of the method of statistical classification is removed - the requirement of equality of covariance matrices. Despite the fact that conclusions are made in relation to twodimensional space, the obtained results can be useful for solving practical problems. These tasks include the task of statistical classification of objects describing the operation of chemical-technological systems. A special feature in this case is the need to identify the part of the process where a deviation from the normal mode of operation occurs. It is possible to talk about, for example, two aggregates of a chemical-technological system, connected in series.

\section{Methods of research}

Parametric methods of pattern recognition, implemented on the results obtained in [1, 15], are chosen as the main research method. The classification rules have a general form (15), and the discriminant function - (16).

$$
\begin{aligned}
& x^{j} \in A, \text { if } P\left(A \mid x^{j}\right) \geq P\left(B \mid x^{j}\right), \\
& x^{j} \in B, \text { if } P\left(A \mid x^{j}\right)<P\left(B \mid x^{j}\right) . \\
& f(x)=x^{\prime} \operatorname{cov}^{-1}(x)\left(m_{A}-m_{B}\right)= \\
& =\frac{1}{2}\left(m_{A}+m_{B}\right)^{\prime} \operatorname{cov}^{-1}(x)\left(m_{A}-m_{B}\right)-\ln \frac{P(A)}{P(B)} .
\end{aligned}
$$


In (15) and (16) the following notation is used: $x^{j}-$ the coordinate of the object in the space of factor-attributes; $\operatorname{cov}(x)$ - covariance matrix:

$$
\operatorname{cov}(x)=\frac{1}{N} X^{T} X-m^{T} m ;
$$

$m_{A}$ and $m_{B}$ - the mathematical expectations of the vector of input variables in the space of factor-attributes for classes $A$ and $B$, respectively; $P(A), P(B)$ - the prior probabilities of classes.

The idea of localizing the class partition area is as follows:

1. In accordance with (15), (16), a separating surface is constructed on the basis of the statistical classification procedure. For two-dimensional space, it is straight.

2. For each class, a convex polyhedron is constructed, the sides of which are the extreme points of the data distribution area - the values of the factor-attributes. Points from which the distance to the center of gravity of the clusters for each class significantly exceeds the average for the corresponding cluster are not taken into account. The assumption is introduced that these points can be qualified as abnormal.

3 . Inside a convex polyhedron for class $A$, circles of $r_{i}$ radius are distinguished. The $r_{i}$ value is chosen arbitrarily in order to inscribe several circles in the selected convex polyhedron covering different regions in the coordinates of feature factors. If assume that objects with similar values of sets of factor signs belong to the same class, which is the main position for classification, then within these circles can distinguish subsets according to certain rules. Such a rule may be, for example, the choice of points in accordance with the plans of a full factorial experiment. In this case, it is possible to speak about the orthogonality of the area of localization of the factor-attributes and the most accurate estimates. Thus, in each of the circles of $r_{i}$ radius, it is possible to inscribe the plan of the full factorial experiment $N=2^{k}$.

4. The plan of the full factorial experiment $N=2^{k}$ fits into each of the circles of $r_{i}$ radius. The vertices of the plan form a set of values of the factors-attributes of each class.

5. Procedure 2 is repeated for class $B$, and in such a way that the distances from the center of the $j$-th plan for class $B$ to the dividing straight line are equal to the distances from the center of the $j$-th plan for class $A$. At the same time, the radii of circles inscribed in a convex polyhedron for the class $B$ are equal to the radii of the circles inscribed in a convex polyhedron for class $A: r_{i}^{j(A)}=r_{i}^{j(B)}$. Consequently, plans are formed with equal legs for classes $A$ and $B$.

Performing these procedures ensures the equality of the covariance matrices of both classes.

\section{Research results}

Fig. 3 shows a demonstration of procedures 2, 3 and the results obtained for the source data given in Table 1.

Fig. 4 shows a demonstration of procedures 4, 5 and the results obtained for the source data given in Table 1.

For the task under consideration, 3 plans were selected, shown in Fig. 3, 4, on the basis of which the values of the coefficients of discriminant functions and its threshold values are calculated for each of those plans.

For plan No. 1 (the plan is inscribed in the upper circle in Fig. 3, 4):

$$
\begin{aligned}
& x^{j} \in A, \text { if }-151.96 x_{1}+13.22314 x_{2} \geq 57.50116, \\
& x^{j} \in B, \text { if }-151.96 x_{1}+13.22314 x_{2}<57.50116 .
\end{aligned}
$$

The density curves of the probability distribution of the values of the discriminant function for both classes and the threshold value for plan No. 1 are shown in Fig. 5.

Values of the discriminant function in Fig. 5 calculated on the left side of equation (17).

For plan No. 2 (the plan is inscribed in the middle circle in Fig. 3, 4):

$$
\begin{aligned}
& x^{j} \in A, \text { if }-154.58 x_{1}+11.57025 x_{2} \geq 58.535174, \\
& x^{j} \in B \text {, if }-154.58 x_{1}+11.57025 x_{2}<58.535174 .
\end{aligned}
$$

The density curves of the probability distribution of the values of the discriminant function for both classes and the threshold value for plan No. 2 are shown in Fig. 6 .

Values of the discriminant function in Fig. 6 are calculated on the left side of equation (18).

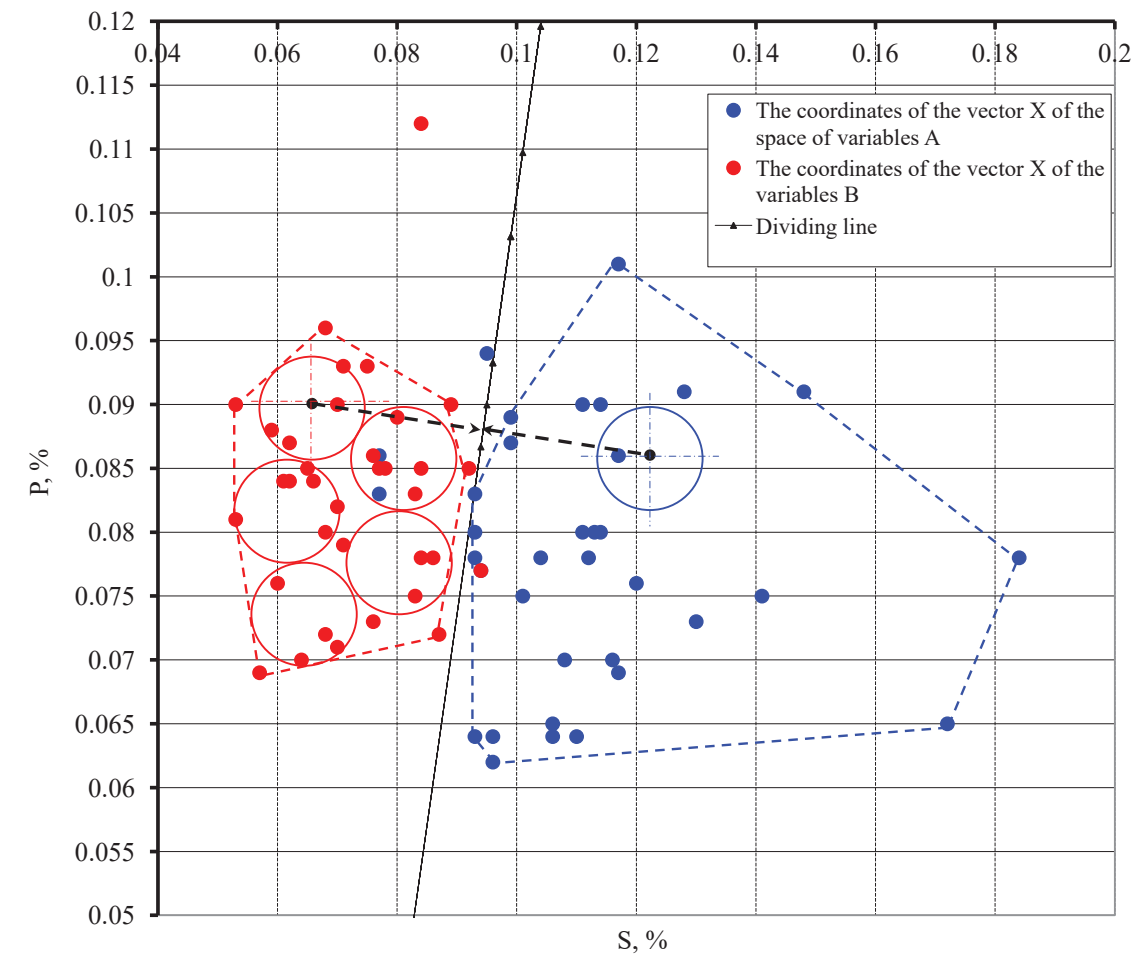

Fig. 3. Localization of the data area for dividing classes in accordance with procedures 2, 3 and the results of the distribution of objects into classes by the implementation of procedure 1 


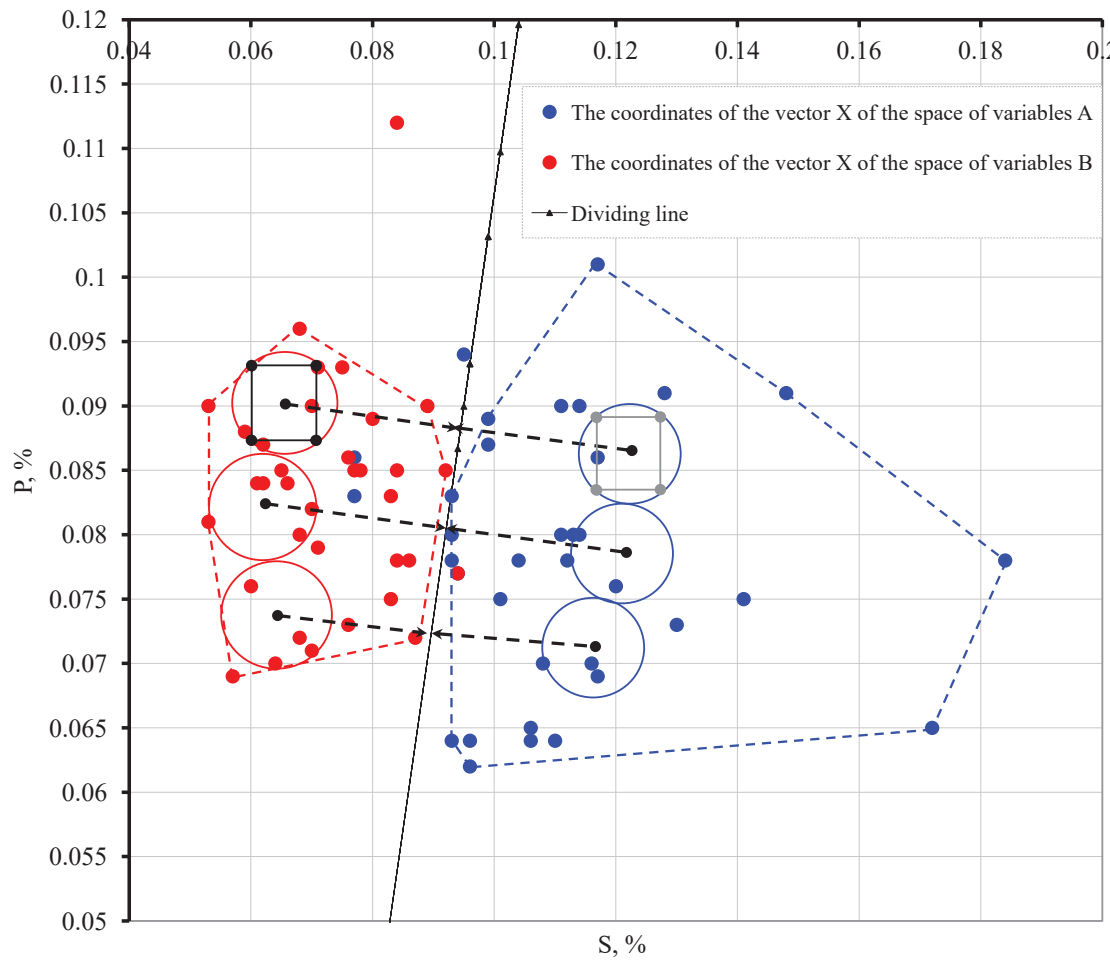

Fig. 4. Demonstration of the implementation principle of procedures 4, 5

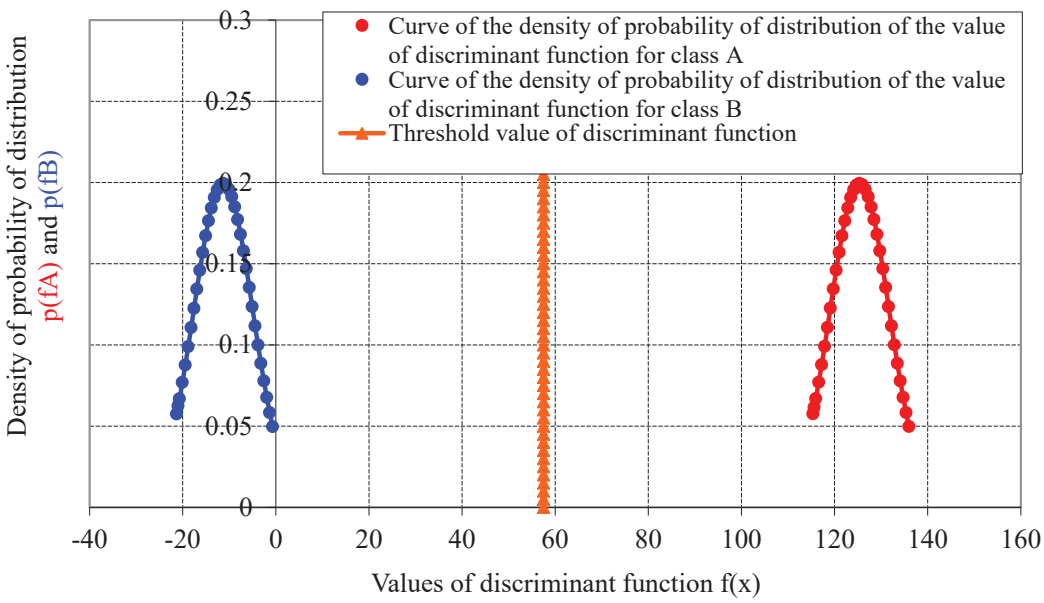

Fig. 5. The density curves of the probability distribution of the values of the discriminant function for both classes and the threshold value for plan No. 1

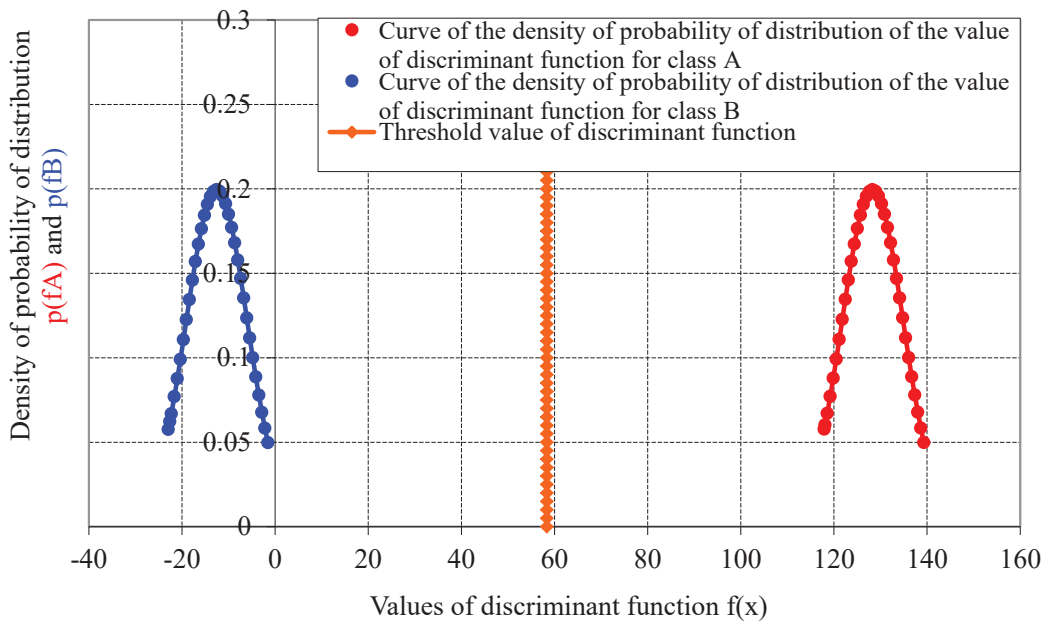

Fig. 6. The density curves of the probability distribution of the values of the discriminant function for both classes and the threshold value for plan No. 2
For plan No. 3 (the plan is inscribed in the lower circle in Fig. 3, 4):

$$
\begin{aligned}
& x^{j} \in A, \\
& \text { if }-141.48 x_{1}+9.917355 x_{2} \geq \\
& \geq 51.38876, \\
& x^{j} \in B, \\
& \text { if }-141.48 x_{1}+9.917355 x_{2}< \\
& <51.38876 .
\end{aligned}
$$

The density curves of the probability distribution of the discriminant function values for both classes and the threshold value for plan No. 3 are shown in Fig. 7.

Values of the discriminant function in Fig. 7 are calculated on the left side of equation (19). Classifying rules of the form (17)-(19) are given in the normalized form.

From the above results, it follows that the position of the plan when choosing points for calculating the discriminant function and constructing classifying rules is important. This is manifested in the fact that the dividing line when changing the position of the plan leads to its inclination relative to the common dividing line, built on the basis of a complete data sample using the standard parametric classification procedure. This conclusion does not contradict the conclusion obtained in [15] and suggests that this way it is possible to improve the classification accuracy.

However, comparing the results obtained with the results given in [1] for the same sample of data, it can be seen that the differences in the position of the dividing line are insignificant (Fig. 8). This is probably due to the fact that the initial data area was well divided in the space of factor-attributes. Therefore, from the standpoint of improving the accuracy of classification, the results obtained may not be as significant in assessing the accuracy of classification for the entire sample as expected. However, it can be assumed that in the case of poorly separable samples, the proposed procedure will give more meaningful results, since the classification accuracy for the samples corresponding to each plan is equal to one. This is a more important result, since it will allow separating linearly non-separable samples in the space of factor-attributes based on the use of the standard statistical parametric classification procedure. 
In this case, the curve separating the classes will have the form of a polyline composed of straight lines with inflection points corresponding to the boundaries of the plans inside the convex polyhedra containing the experimental points.

Fig. 8 shows the arrangement of the dividing straight lines for plans No. 1-3 with respect to the common dividing straight line, constructed from the general complete sample of the data given in Table 1. It is important to note here that the position of these three straight lines, corresponding to plans No. $1-3$, Fig. 8 are indicated in general, without reference to the location of plans inside convex polyhedra.

Demonstration of the general picture of the location of the dividing lines with regard to the location of the plans is shown in Fig. 9.
It is important to say that only three plans were considered to demonstrate the principle of constructing a dividing polyline based on the use of the standard parametric classification procedure.

Therefore, the direction of development of this research can be the identification of patterns and the construction of a mathematical model linking the location of plans with the accuracy of classification and the form of the separating curve. Such a model can be constructed, for example, on the basis of applying the plan of a full factorial experiment, choosing as input variables the angle of inclination and the radius-vector of the position of the center of the $i$-th plane relative to the origin. A point with coordinates $(0 ; 0)$ in the normalized space of factor-attributes can be selected as the origin of coordinates.

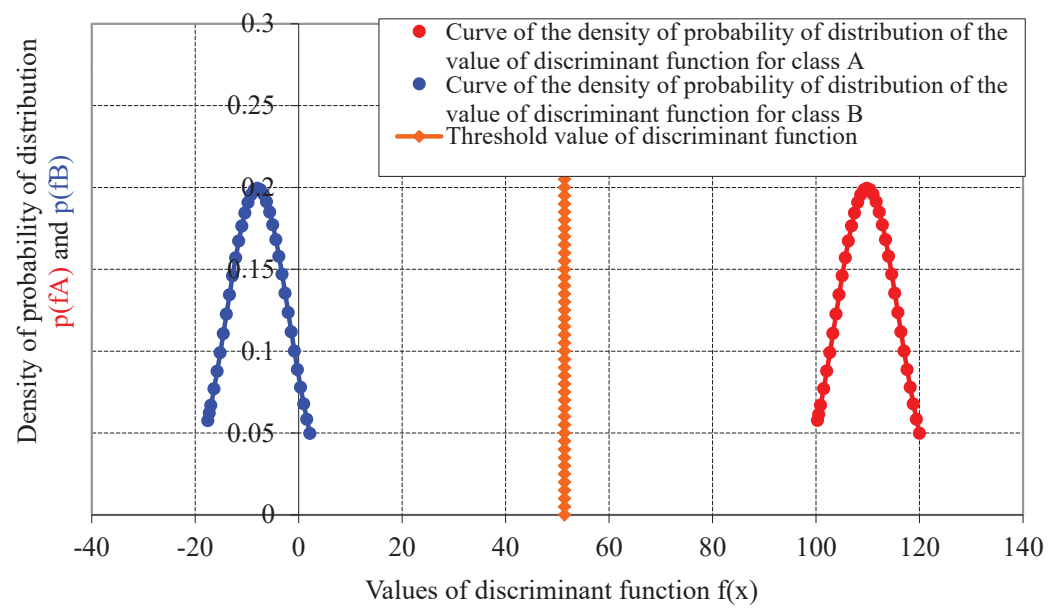

Fig. 7. The density curves of the probability distribution of the values of the discriminant function for both classes and the threshold value for plan No. 3

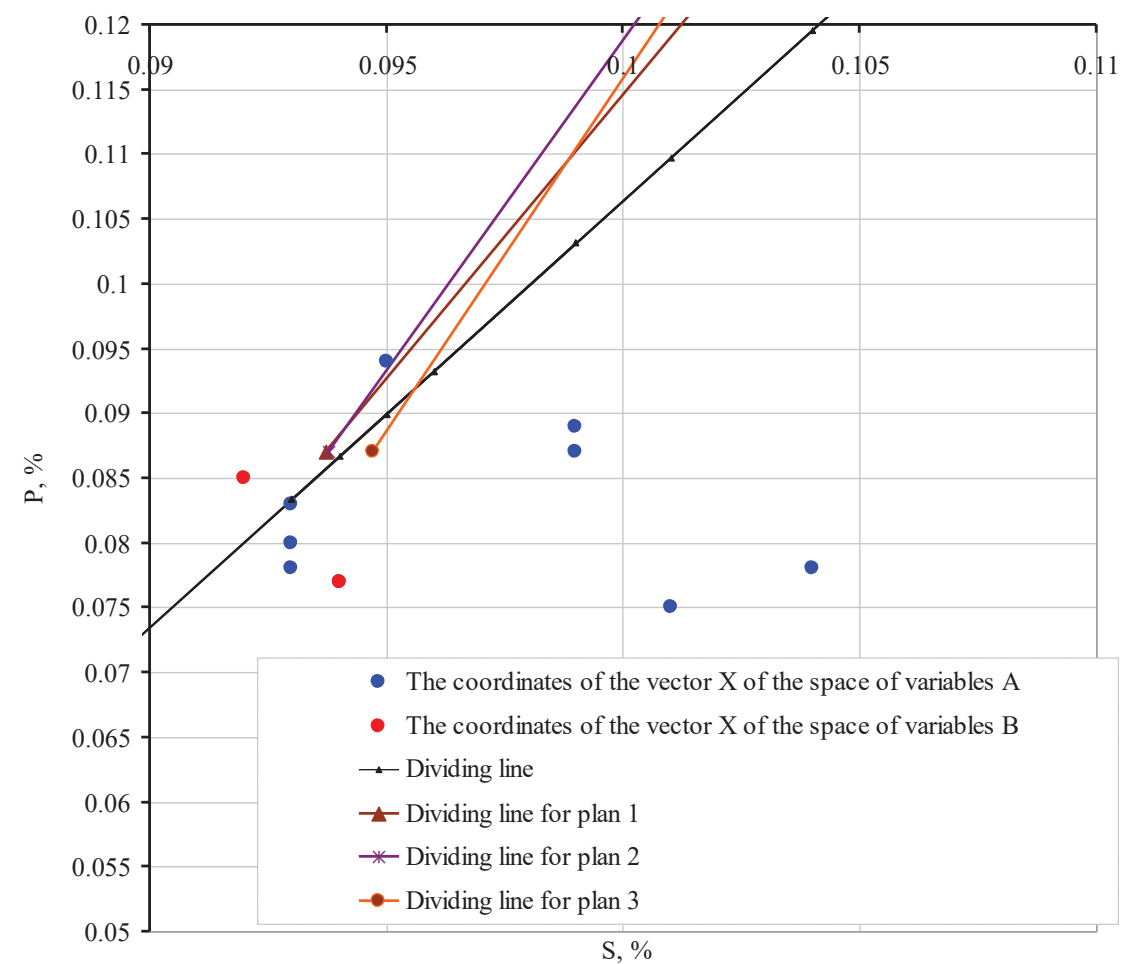

Fig. 8. The position of the dividing lines when choosing different plans for calculating the coefficients of discriminant functions 


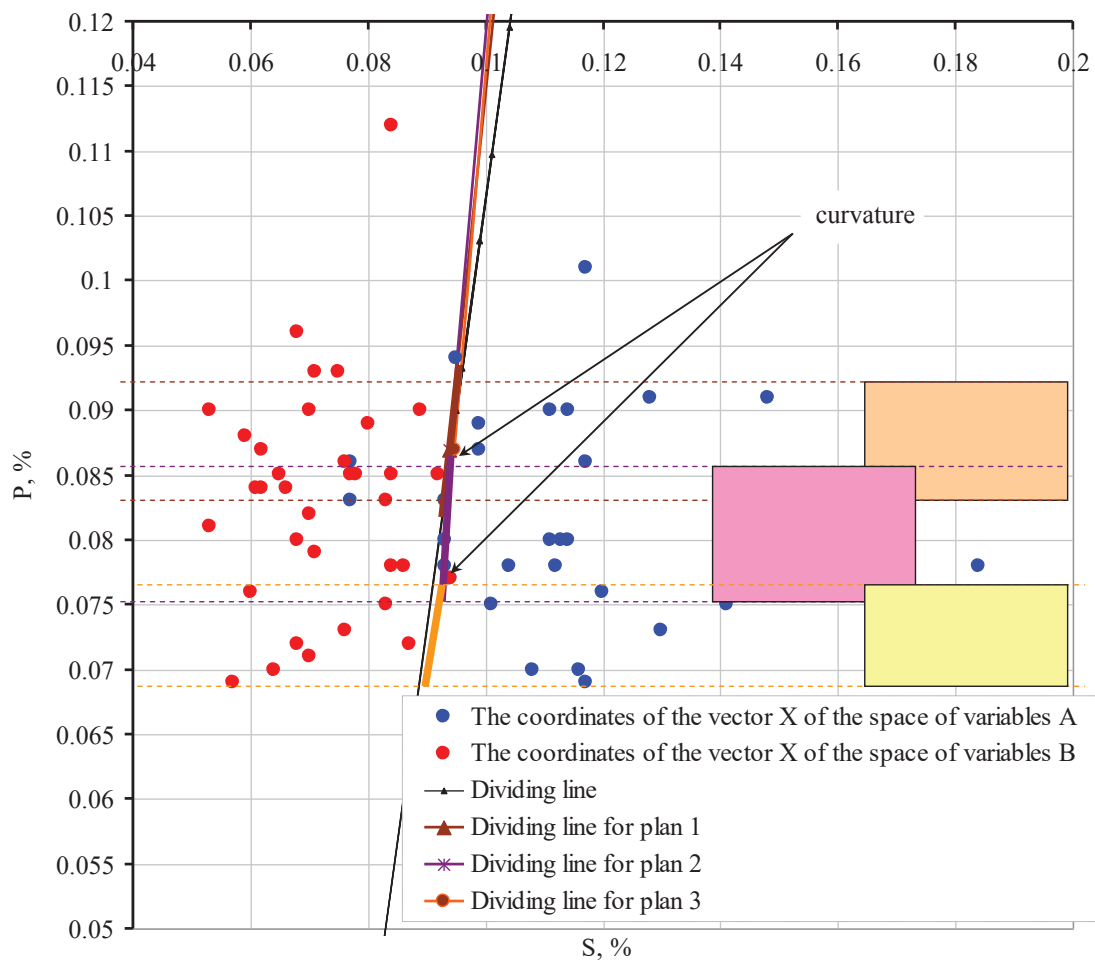

Fig. 9. Dividing polyline: $\square$ - plan No. 1; $\square$ - plan No. 2; $\square$ - plan No. 3

\section{SWOT analysis of research results}

Strengths. Among the strengths of this research, it is necessary to note the possibility of obtaining a classifying rule based on the standard parametric classification procedure, however, in the case of linearly inseparable samples. The practical side of this result is that the classification rules obtained using such a procedure can provide more accurate diagnostic data. As part of the decision-making systems, this will enable more accurate operator exposure to the chemical process system. This can prevent possible consequences with system element failures. In the considered practical example, an accurate classification will allow to identify the cause of violations during the process. In turn, such violations lead to poor desulfurization and dephosphorization, that is, to a reduction in the quality of the finished product.

Weaknesses. The weaknesses of this research are related to the fact that the results obtained are not significant enough from the point of view of improving the classification. The original data sample was fairly well separable, which is not often. Therefore, for practical conditions it was possible to use the solutions obtained on the basis of the standard procedure.

Opportunities. Opportunities when using the given results in industrial conditions are connected with the use of the received classifying rule in information systems of decision support. Any positive results in this sense can be useful for improving the processes of desulfurization and dephosphorization. And it is possible to talk both for the considered chemical-technological systems, where decisions are made by operators, and for automated systems.

Threats. Obvious risks when using the obtained results are related to the fact that the use of the obtained classification rules as a basis for information management systems should be justified from the point of view of cost comparison. These costs relate to the modernization of equipment or control systems and the acquisition of ready-made solutions for SCADA-systems. Considering that the presented results are of a more demonstrative character - from the point of view of mathematical description - it is premature to consider the question of the full practical use of the rules obtained. First of all, it is necessary to identify general laws that will allow to systematize the decisions obtained concerning the complete system of classifying rules.

\section{Conclusions}

1. It is proposed to choose the area of the source data for the construction of classifying rules based on a sequential procedure that includes 5 steps. The first step is building classification rules based on a common data sample by applying a standard parametric classification procedure. The following steps can be viewed as a modification of the method for calculating the coefficients of the discriminant function in the part that concerns the targeted selection of the source data area. This procedure provides the possibility of removing one of the restrictions on the application of the method of parametric classification associated with the requirement of equality of covariance matrices. This is done by selecting the source data area based on the construction of plans for a full factorial experiment. The procedure is demonstrated by the example of selecting the source data area for constructing classifying rules that allow assessing the quality of the processes of desulfurization and dephosphorization of $\mathrm{Fe}-\mathrm{C}$ melt.

2. It is established that the location of the areas of the initial data for the construction of classifying rules 
affects the position of the line dividing the classes. Each of these classes corresponds to its unit of the considered chemical-technological system consisting of two units connected in series. A change in the position of the dividing line is manifested in a change in the values of the coefficients of the discriminant function. As a result, for each area of the initial data corresponding to the location of the plan of the full factorial experiment, its own angle of inclination and position of the dividing line is formed. This makes it possible to obtain a broken dividing curve using the standard parametric classification procedure. This conclusion is demonstrated by the example of calculating the coefficients of the discriminant function for constructing a broken dividing curve in the space of the S-P factor-attributes. The resulting classification rules allow to identify the part of the chemical-technological system that causes deviations from the normal mode of operation in terms of the desulfurization and dephosphorization processes of the $\mathrm{Fe}-\mathrm{C}$ melt.

\section{References}

1. Aouati M. Parametric identification in the problem of determining the quality of dusulfusation and deposphoration processes of Fe-C alloy // Technology Audit and Production Reserves. 2017. Vol. 2, Issue 1 (34). P. 9-15. doi: http://doi.org/ 10.15587/2312-8372.2017.99130

2. Metallurgiia plavki chuguna v dugovoi pechi / Grachev V. A., Kuznecov B. L., Bochkarev V. E., Venger V. V. // Liteinoe proizvodstvo. 1988. Issue 2. P. 19-21.

3. Shulte Iu. A. Proizvodstvo otlivok iz stali. Kyiv; Doneck: Vishcha shkola. Golovnoe izd-vo, 1983. 184 p.

4. Pavlenko V. D., Fomin A. A. Povyishenie tochnosti postroeniya reshayuschego pravila v metodah statisticheskoy klassifikatsii // Elektronnoe modelirovanie. 2001. Vol. 23, Issue 4. P. 61-68.

5. Vasenko Y. Technology for improved wear iron // Technology Audit and Production Reserves. 2012. Vol. 1, Issue 1 (3). P. 17-21. doi: http://doi.org/10.15587/2312-8372.2012.4870

6. Ponomarenko O. I., Trenev N. S. Computer modeling of crystallization processes as a reserve of improving the quality of pistons of ICE // Technology Audit and Production Reserves. 2013. Vol. 6, Issue 2 (14). P. 36-40. doi: http://doi.org/ $10.15587 / 2312-8372.2013 .19529$
7. Ignaszaka Z., Popielarskia P., Krawiecb K. Contribute to quantitative identification of casting defects based on computer analysis of X-ray images // Archives of foundry engineering. 2007. Vol. 7, Issue 4 (18/4). P. 89-94.

8. Lin Z., Lyu M. R., King I. MatchSim: a novel similarity measure based on maximum neighborhood matching // Knowledge and Information Systems. 2011. Vol. 32, Issue 1. P. 141-166. doi: http://doi.org/10.1007/s10115-011-0427-z

9. Arsirii E., Manikaeva O., Vasilevskaia O. Development of the decision support subsystem in the systems of neural network pattern recognition by statistical information // Eastern-European Journal of Enterprise Technologies. 2015. Vol. 6, Issue 4 (78). P. 4-15. doi: http://doi.org/10.15587/1729-4061.2015.56429

10. Fraze-Frazenko A. Algorithm of study neural network for image recognition // Technology Audit and Production Reserves. 2012. Vol. 4, Issue 1 (6). P. 33-34. doi: http://doi.org/ $10.15587 / 2312-8372.2012 .4781$

11. Fertsev A. A. Uskorenie obucheniya neyronnoy seti dlya raspoznavaniya izobrazheniy s pomoschyu tehnologii NVidia Cuda // Vestnik Samarskogo gosudarstvennogo tehnicheskogo universiteta. 2012. Vol. 1, Issue 26. P. 183-191. doi: http:// doi.org/10.14498/vsgtu990

12. Unglert K., Radić V., Jellinek A. M. Principal component analysis vs. self-organizing maps combined with hierarchical clustering for pattern recognition in volcano seismic spectra // Journal of Volcanology and Geothermal Research. 2016. Vol. 320. P. 58-74. doi: http://doi.org/10.1016/j.jvolgeores.2016.04.014

13. Fuzzy pattern recognition-based approach to biometric score fusion problem / Fakhar K., El Aroussi M., Saidi M. N., Aboutajdine D. // Fuzzy Sets and Systems. 2016. Vol. 305. P. 149-159. doi: http://doi.org/10.1016/j.fss.2016.05.005

14. Perova I. G. Adaptive treatment of these medico-biological researches by methods of computational intelligence // Eastern-European Journal of Enterprise Technologies. 2014. Vol. 1, Issue 4 (67). P. 24-28. doi: http://doi.org/10.15587/1729-4061.2014.21202

15. Aouati M. Localization of vectors-patterns in the problems of parametric classification with the purpose of increasing its accuracy // Eastern-European Journal of Enterprise Technologies. 2016. Vol. 4, Issue 4 (82). P. 10-20. doi: http://doi.org/ $10.15587 / 1729-4061.2016 .76171$

Aouati Mourad, Chief Commissioner of Police, Central City Police Department of Constantine, Constantine, Algeria, Postgraduate Student, Department of Foundry, National Technical University «Kharkiv Polytechnic Institute», Ukraine, e-mail: ayamu2005@yahoo.fr, ORCID: http://orcid.org/0000-0003-2744-3592 